\title{
ADDRESSING THE SMALL BUSINESS TAX COMPLIANCE BURDEN - EVIDENCE FROM SOUTH AFRICA
}

\author{
Sharon Smulders" \\ The South African Institute of Tax Practitioners \\ smulders@thesait.org.za
}

\author{
Gelishan Naidoo+ \\ Sasol Ltd \\ Gelishan.naidoo@sasol.com
}

September 2011

\begin{abstract}
Small businesses have the potential to grow the economy, generate jobs and reduce poverty, but they face many constraints including high tax compliance costs and burdens. A comparison of the findings and recommendations made in small business tax compliance cost studies conducted in South Africa with initiatives introduced by the South African Revenue Service (SARS), substantiated by consultations with a SARS and a South African Institute of Chartered Accountants official, reveals that SARS has, in most cases, attempted to address the tax compliance burdens identified in these studies. However, SARS has only partially addressed the complexity of the tax law, the lack of software to assist small businesses with their record-keeping and the compliance burden associated with provisional tax. SARS has failed to address the need for a threshold below which no small business tax return is required to be submitted, the inclusion of tax in the school syllabus, the requirement for first-time offenders to attend courses instead of raising penalties and the need for a reduction in the rates of interest and penalties raised by SARS. These initiatives should be considered by SARS and it is recommended that further research into the success and effectiveness of all the initiatives already introduced by SARS be performed.
\end{abstract}

Keywords

Small business, South African Revenue Service (SARS), Tax compliance burden, Tax compliance costs, Tax initiatives

\#Ms Sharon Smulders is the Head of Tax Technical and Research at the South African Institute of Tax Practitioners (SAIT), South Africa

+Mr Gelishan Naidoo is a Financial Manager in the Taxation Department at Sasol Ltd, Johannesburg, South Africa 


\section{INTRODUCTION}

Small, medium and micro enterprises (SMMEs) - hereafter referred to as small businesses - are important mechanisms for addressing the challenges of job creation, economic growth and equity in South Africa (Department of Trade and Industry (DTI), 2005:7). Since 1994, the South African government has recognised its important role in fostering an enabling environment for the creation and growth of small businesses. (DTI, 2005:3; National Treasury, 2011:46).

Despite this sector's importance to the economy, tax compliance requirements and high tax compliance costs have been identified as an impediment for small businesses in South Africa (Abrie \& Doussy, 2006:1; FIAS, 2007; Hassan 2011:1; Retief, 2011:2; South African Revenue Service (SARS), 2009a:4; Small Business Project, 2003:1). Thus the South African government has recognised that an important priority of theirs is to make the tax regulatory environment friendlier for the small business sector (SARS, 2008a:46; 2008b). In 2005, the process of change in SARS commenced. The intention was that the changes would assist small businesses in their start-up phase, reduce compliance costs and administrative complexity (red-tape), and include tax education and assistance (Manuel, 2005:1).

Despite these intentions, it appears that tax compliance costs remain regressive, placing a greater burden on smaller businesses (FIAS, 2007; Small Business Project, 2003). SARS (2009b:4) confirms this, stating that small businesses face many barriers, including relatively high tax compliance costs as a percentage of turnover.

\section{RATIONALE FOR THE STUDY AND RESEARCH AIM}

SARS (2008b) claims to be attempting to reduce the small business tax compliance burden (the time and costs spent on complying with the tax system (Guyton et al., 2003)). However, this is not the perception of Abrie and Doussy (2006:1), FIAS (2007:1), Hassan (2011:1), Pabaka (2011:17) and Retief (2011:2), who all argue that the tax system and its compliance requirements are a stumbling block to the growth of small businesses in South Africa.

This study thus aims to establish whether or not SARS has introduced initiatives that have bearing on South African small businesses' tax compliance needs. This will assist in determining if SARS is aware of small businesses' tax compliance burdens documented in tax compliance cost studies and if it has attempted to address these burdens. This review will highlight the gaps or neglected area/s that SARS could focus its attention on in the future.

\section{LIMITATIONS OF THE STUDY}

The first limitation is that this study does not aim to determine the success or effectiveness of the SARS initiatives, as this would require further in-depth research of each initiative and this is beyond the scope of this research.

The second limitation is that although small businesses may consider there to be numerous tax compliance burdens that their businesses encounter, this study considers only those tax burdens that have been documented in freely available published tax compliance cost studies. 
The third limitation is that no small businesses were interviewed to get their perceptions on this matter because there is no scientifically valid universe or reliable database of small businesses from which to select the desired respondents (African Response, 2006:11; FinScope, 2010:4; Statistics South Africa, 2010:vii). Instead an interview was conducted with a SAICA official, who in his official capacity, represents tax practitioners that assist small businesses with their tax affairs. This is regarded as prudent as it has been established that between 57 and 80 per cent of small businesses use tax practitioners to assist them with their tax compliance requirements (Coolidge et al., 2009; De Clercq et al., 2006; FIAS, 2007; Tustin et al., 2005; Upstart Business Strategies, 2004; Venter \& De Clercq, 2007).

\section{RESEARCH METHODOLOGY}

The research followed a three-step process. The first step comprised a literature review conducted to establish the existence and nature of the tax compliance burdens faced by small businesses as documented in tax compliance cost studies. The second step consisted of a content analysis of the SARS website to determine whether any SARS initiatives could be considered to be addressing the tax compliance burdens (as established in the literature review) faced by small businesses. These initiatives were then linked to the tax compliance burdens in a tabular format. The third step involved interviews with a SARS and a SAICA official in order to confirm the completeness and validity of the findings in steps one and two.

The interview with the SARS official (Mr P Silenga, SARS Senior Specialist for Small Businesses) was conducted on 22 March 2012, in order to ascertain whether SARS included the findings and recommendations made in the tax compliance costs studies when considering initiatives for the small business sector. The interview was also conducted to establish if there were any SARS initiatives that did not appear on the SARS website that had bearing on the small business's tax compliance burdens (a completeness check) and if there were any future initiatives that SARS was considering and could divulge for the purposes of this research.

The interview with the SAICA official (Mr P. Nel, SAICA Project Director of Tax) was conducted on 27 March 2012, in order to validate the findings of the literature and the SARS website review from the perspective of tax practitioners who assist small businesses with their tax affairs. The official's insight also provided further confirmation that all the SARS initiatives that could be regarded as addressing the tax compliance burden for small businesses had been considered in the research.

Both the officials were asked to validate the findings made by the researchers as to whether or not the SARS's initiatives had attempted to address each tax compliance burden. Their opinions on the success and effectiveness of these initiatives were not asked as this is beyond the scope of this research.

This triangulation of data between the literature, the SARS website and the perspectives of the SARS and SAICA officials increases the confidence in the current study's findings as it provides an analysis of the research from multiple perspectives, thereby providing a more comprehensive view of the research problem and findings (Cooper \& Schindler, 2008:185-186). 


\section{FINDINGS OF STUDY}

\subsection{Literature review}

Smulders (2006) provided the first ever overview of the research concerning tax compliance costs for small businesses in South Africa. Some years have elapsed since that study, and there has subsequently been additional research in this area. This study, therefore, updates and expands on the list of tax compliance costs studies provided by Smulders (2006). A list of the studies documented by Smulders (2006:58-59) and taken into account in this study are contained in Annexure A. The subsequent studies that deal, either completely or to some extent, with the tax compliance burden or costs for small businesses in South Africa are contained in Annexure B.

\subsection{Comparison of burdens with SARS's initiatives}

Before embarking on the comparison of the tax compliance burdens found in the studies reviewed with the initiatives introduced by SARS, the question as to whether SARS considers and is influenced by tax compliance cost studies has to be addressed, because this study is meaningless if this is not the case. Mr Selinga from SARS confirmed that this is indeed the case. He also mentioned additional methodologies that SARS employs to ensure that they are aware of the tax compliance issues faced by small businesses. These include:

- interviews with heads of the various business associations (such as, inter alia, the Business Unity South Africa and the Gauteng Enterprise Propeller); interviews with the banking sector;

- investigative research (for instance, obtaining information not publicly available by using forensic auditors);

- modelling data that SARS already has in its possession; and

- obtaining information from the small businesses themselves.

Having confirmed that SARS does indeed consider the findings and recommendations of tax compliance cost studies in their endeavours to reduce the tax compliance burden faced by small business, the findings of these studies were reviewed and the tax compliance burdens contained in each study were summarised (refer to TABLE 1). Certain of the studies (FIAS, 2008; World Bank \& International Finance Corporation, 2006 to 2011) did, however, not provide a specific tax compliance burden and were, therefore, not taken into account in TABLE 1 .

A concurrent content analysis of the SARS website was then performed to identify the SARS initiatives since 2001 - the year it launched its first small business initiative (National Treasury, 2001:79) - that could be regarded as an attempt to address the small business tax compliance burdens found in the research studies. These initiatives were then linked to the burdens in TABLE 1. Comparing the burdens with the initiatives highlights the lacunae in such initiatives, indicating where SARS could consider focusing its attention in future.

TABLE 1 also includes the year in which the study was published (not necessarily performed) and the year in which SARS instituted an initiative that addressed the compliance burden. This could be seen as an indication of how long SARS took to respond to the tax compliance burdens identified by the research studies. However, this can, at best, only be regarded as a rough estimate rather than an accurate measurement of SARS's response time in addressing the 
compliance burdens identified. There are various reasons for this. One is that some studies were published a while after the research took place, so that the burden possibly existed for longer than suggested by the publication date of the study. Furthermore, SARS could have been aware (by means of their own surveys, for instance) of the compliance burden long before the research study identified it, and could have started planning its compliance initiative/s months, or even years, before implementation. Thus, although this time period can be calculated, it should be interpreted with caution.

TABLE 1 below summarises the tax compliance burdens found in the studies (column 1) and indicates the initiative/s SARS introduced that could be regarded as addressing the burden (column 2). The extent to which the compliance burden could be seen as an attempt to address (either completely, or to some extent, or not at all) the tax compliance burden is also indicated (in column 3) and the validation of these findings by the SARS and SAICA official is also specified in this last column.

\section{TABLE 1: Comparison of the tax compliance burdens to SARS's initiatives}

\begin{tabular}{|c|c|c|}
\hline Compliance burden & SARS initiatives & $\begin{array}{l}\text { SARS attempted to } \\
\text { address the burden? }\end{array}$ \\
\hline $\begin{array}{l}\text { Complex tax } \\
\text { registration process, } \\
\text { especially registration } \\
\text { for VAT } \\
\text { (Clover \& Darroch, } \\
2005 ; \text { FIAS, 2007) }\end{array}$ & $\begin{array}{l}\text { - SARS combined the Skills Development Levy } \\
\text { (SDL), Unemployment Insurance Fund (UIF) and } \\
\text { pay-as-you-earn (PAYE) registration forms into } \\
\text { one form (SARS, 2003:59). } \\
\text { - From I August 2005, employers were not required } \\
\text { to register for SDL if the total leviable amount did } \\
\text { not exceed R500 } 000 \text { (previously R250 000) (SARS, } \\
2005 \text { b). } \\
\text { - The VAT registration process was simplified in } \\
\text { February } 2008 \text { (SARS, } 2008 \text { c). } \\
\text { - } \text { According to the SARS official, further } \\
\text { simplification and automation (such as biometric } \\
\text { testing) of this process is currently being } \\
\text { developed by SARS]. } \\
\text { SARS increased the compulsory VAT registration } \\
\text { threshold from R300 } 000 \text { to Rlm from } 1 \text { March } \\
2009 \text { (SARS, } 2009 \mathrm{c} \text { ). }\end{array}$ & $\begin{array}{l}\text { - Yes } \\
\text { - This was } \\
\text { confirmed by } \\
\text { both the SARS } \\
\text { and SAICA } \\
\text { officials. }\end{array}$ \\
\hline $\begin{array}{l}\text { Two of the most } \\
\text { burdensome taxes for } \\
\text { small businesses are } \\
\text { VAT } \\
\text { (Citizen Surveys \& } \\
\text { Govender, 2008; FIAS, } \\
\text { 2008; SARS, 2005a; } \\
\text { Strategic Business } \\
\text { Partnerships (SBP), } \\
2005 \text {; Upstart Business } \\
\text { Strategies, 2004) }\end{array}$ & $\begin{array}{l}\text { - Small retailers VAT package was introduced in } \\
\text { April } 2005 \text { (National Treasury, 2005:88). } \\
\text { - A specific initiative for educating SMEs on VAT } \\
\text { was undertaken in } 2005 \text { (National Treasury, } \\
\text { 2005:88). } \\
\text { - Small businesses with taxable supplies of less } \\
\text { than Rlm could, from 2005, file their VAT returns } \\
\text { every four months instead of every two months } \\
\text { (National Treasury, 2005:88). } \\
\text { - A simplified turnover-based tax system for micro } \\
\text { businesses was introduced from } 1 \text { March } 2009\end{array}$ & $\begin{array}{l}\text { - } \text { Yes } \\
\text { - This was } \\
\text { confirmed by } \\
\text { both the SARS } \\
\text { and SAICA } \\
\text { officials. }\end{array}$ \\
\hline
\end{tabular}




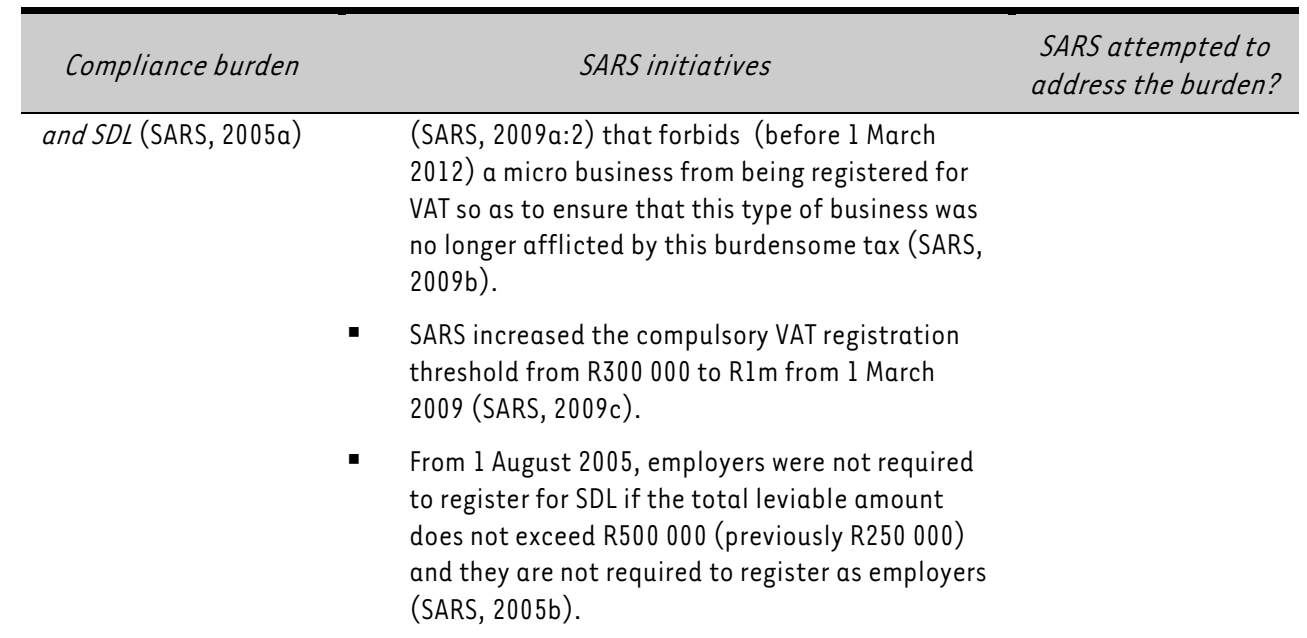

\section{Too many forms and procedures in filing for tax, high frequency of submission of tax returns}

(SARS, 2005a)
- Small business with taxable supplies of less than Rlm could, from 2005, file their VAT returns every four months instead of every two months (National Treasury, 2005:88).

- Introduction of efiling of VAT returns in 2001 (SARS, 2001; SARS, 2009d) and PAYE returns in 2008 (SARS, 2008d; SARS, 2008e).

- efilers given more time to file their returns from 2007 (SARS, 2008f).

- From 1 March 2012, businesses on the turnover tax system can submit their VAT and employees' tax returns twice per year (SARS, 2012b:6).

- It is further envisaged that a single combined return will be filed on a twice-yearly basis from 1 March 2013 (SARS, 2012b:6).
- Yes

- This was confirmed by both the SARS and SAICA officials.
Tax laws written in too complex language

(Abrie \& Doussy, 2006; Citizen Surveys \& Govender, 2008; FIAS, 2007; SARS, 2005a)
- Advanced tax rulings intended to promote clarity, consistency, and certainty in respect of the interpretation and application of the tax laws could be obtained by small businesses from 2006 (SARS, 2010a), but for a fee in certain cases (SARS, 2009k).

- SARS introduced the simplified turnover-based tax system from 1 March 2009 (SARS, 2009a:2), but this has technical anomalies (SARS, 2010a; Smulders \& Stiglingh, 2009).

- Simplification of wording in the Act (rewrite) mentioned in 2009 Budget Speech, but only the customs and excise Acts are in the process of being rewritten and are not enacted to date (SARS, 2009e:17).

- The introduction of the Tax Administration Bill in 2011 (Act promulgated in 2012 but not yet
- Partially as the law (even the supposedly simple turnover tax legislation) is still written in a complex manner.

- The SARS official confirmed that SARS (along with the National Treasury) is trying to simplify the tax legislation itself but this has not yet been fully 


\begin{tabular}{|c|c|c|}
\hline Compliance burden & SARS initiatives & $\begin{array}{l}\text { SARS attempted to } \\
\text { address the burden? }\end{array}$ \\
\hline & $\begin{array}{l}\text { effective at the time of writing this article) seeks } \\
\text { to facilitate tax compliance by incorporating into } \\
\text { one piece of legislation certain generic } \\
\text { administrative provisions and to provide } \\
\text { consistency in the application of tax law (SARS, } \\
\text { 2009i; } 2011 \text { a: } 1 \text { ) } \\
\text { - [The SARS official mentioned that the } \\
\text { simplification of language is taken into account } \\
\text { in new products currently being developed by } \\
\text { SARS]. }\end{array}$ & $\begin{array}{l}\text { achieved. This } \\
\text { was also } \\
\text { confirmed by the } \\
\text { SAICA official. }\end{array}$ \\
\hline $\begin{array}{l}\text { Tax compliance costs } \\
\text { tend to be regressive, } \\
\text { and are a more onerous } \\
\text { burden for small } \\
\text { businesses than for } \\
\text { larger ones } \\
\text { (SARS, } 2005 \mathrm{a} \text { ) }\end{array}$ & $\begin{array}{l}\text { The simplified turnover-based tax system for } \\
\text { micro businesses (businesses with a turnover of } \\
\text { Rl million or less) was introduced from l March } \\
2009 \text {, the main aim being to reduce their tax } \\
\text { compliance burden. This could now be done by } \\
\text { reducing the need for a tax practitioner to assist } \\
\text { a small business with its tax affairs (SARS, } \\
2009 a: 2 \text { ). }\end{array}$ & $\begin{array}{l}\text { - } \text { Yes } \\
\text { This was } \\
\text { confirmed by } \\
\text { both the SARS } \\
\text { and SAICA } \\
\text { officials. }\end{array}$ \\
\hline $\begin{array}{l}\text { Tax software for } \\
\text { record-keeping could } \\
\text { reduce the tax burden } \\
\text { significantly } \\
\text { (Upstart Business } \\
\text { Strategies, 2004) }\end{array}$ & $\begin{array}{l}\text { - No software for record-keeping has been } \\
\text { provided by SARS other than for the turnover tax } \\
\text { system (SARS, 201la). }\end{array}$ & $\begin{array}{l}\text { - Partially as it is } \\
\text { only available for } \\
\text { the turnover tax } \\
\text { system. } \\
\text { - This was } \\
\text { confirmed by } \\
\text { both the SARS } \\
\text { and SAICA } \\
\text { officials. }\end{array}$ \\
\hline $\begin{array}{l}\text { Tax software, } \\
\text { specifically for VAT, } \\
\text { could reduce the } \\
\text { burden significantly } \\
\text { (Abrie \& Doussy, 2006; } \\
\text { Upstart Business } \\
\text { Strategies, 2004) }\end{array}$ & $\begin{array}{l}\text { - Introduction of efiling of VAT returns in } 2001 \\
\text { (SARS, 2001; SARS, 2009d). } \\
\text { - Small retailers' VAT package was introduced in } \\
\text { April } 2005 \text { (National Treasury, 2005). } \\
\text { - E@syfile software was introduced in } 2008 \text { (SARS, } \\
2008 d \text { ). } \\
\text { - Electronic submission of VAT } 201 \text { returns could be } \\
\text { done from 1 April } 2011 \text { (SARS, } 2011 \mathrm{~b}: 1 \text { ) }\end{array}$ & $\begin{array}{l}\text { - } \text { Yes } \\
\text { - This was } \\
\text { confirmed by } \\
\text { both the SARS } \\
\text { and SAICA } \\
\text { officials. }\end{array}$ \\
\hline $\begin{array}{l}\text { SARS takes, on average, } \\
7 / 8 \text { minutes to answer } \\
\text { incoming calls and } \\
\text { makes, on average, } \\
\text { approximately } 3 / 5 \\
\text { telephone calls to } \\
\text { effectively address tax } \\
\text { enquiries } \\
\text { (De Clercq et al., } 2006 \text {; }\end{array}$ & $\begin{array}{l}\text { - Tax practitioner call-centre centralised, } \\
\text { additional staff obtained during filing season } \\
\text { (Smulders \& Stiglingh, 2008:623). } \\
\text { - [The SARS official mentioned that from } 2010 \text { the } \\
\text { caller resolution rate (time to resolve a query) } \\
\text { has improved. Further, more qualified and } \\
\text { specialised staff have been allocated to } \\
\text { answering the calls and contact centres as } \\
\text { opposed to call centres have been established in }\end{array}$ & $\begin{array}{l}\text { - } \text { Yes } \\
\text { - This was } \\
\text { confirmed by } \\
\text { both the SARS } \\
\text { and SAICA } \\
\text { officials. }\end{array}$ \\
\hline
\end{tabular}




\begin{tabular}{|c|c|c|}
\hline Compliance burden & SARS initiatives & $\begin{array}{l}\text { SARS attempted to } \\
\text { address the burden? }\end{array}$ \\
\hline $\begin{array}{l}\text { Tustin, de Clercq \& } \\
\text { Venter, 2006) }\end{array}$ & $\begin{array}{l}\text { certain areas and they have been provided with } \\
\text { more capabilities (for instance, ability to do } \\
\text { account maintenance transactions) than } \\
\text { before]. }\end{array}$ & \\
\hline $\begin{array}{l}\text { SARS takes } \\
\text { approximately } 10 \text { weeks } \\
\text { to return refunds on } \\
\text { VAT, while its takes } \\
\text { approximately } 13 / 15 \\
\text { weeks to return refunds } \\
\text { on tax returns } \\
\text { (De Clercq et al., 2006; } \\
\text { Tustin et al., 2006) }\end{array}$ & $\begin{array}{l}\text { Quicker assessment/ payment made into } \\
\text { taxpayers' bank accounts owing to efiling of } \\
\text { returns (Smulders \& Stiglingh, 2008:623). } \\
\text { - A VAT refund dashboard was introduced on } \\
26 \text { September } 2011 \text {. This dashboard allows } \\
\text { taxpayers to view the reasons why their refunds } \\
\text { may not have been paid out and what actions } \\
\text { may be required of the taxpayer (SARS, } 2011 \mathrm{c} \text { ). } \\
\text { - } \text { The SARS official indicated that the automation } \\
\text { in } 2010 \text { of the risk profile of its taxpayers has also } \\
\text { improved the ability of SARS to pay out the VAT } \\
\text { refunds to businesses]. } \\
\text { [According to the SARS official, SARS has } \\
\text { introduced an automated risk assessment } \\
\text { process from } 2012 \text { which made turnaround time } \\
\text { quicker and easier, thus ensuring that vendors } \\
\text { get their refunds sooner]. }\end{array}$ & $\begin{array}{l}\text { - Yes } \\
\text { - This was } \\
\text { confirmed by } \\
\text { both the SARS } \\
\text { and SAICA } \\
\text { officials. }\end{array}$ \\
\hline $\begin{array}{l}\text { SARS takes just over a } \\
\text { month to respond to } \\
\text { written correspondence } \\
\text { and eight weeks to } \\
\text { process tax returns } \\
\text { (De Clercq et al., 2006) }\end{array}$ & $\begin{array}{l}\text { - Introduction of efiling of certain tax returns in } \\
2001 \text { (SARS, 2001; SARS, } 2009 \mathrm{~d} \text { ). } \\
\text { - Introduction of an automated assessment } \\
\text { process using a sophisticated risk tool to flag } \\
\text { suspect activities in } 2007 \text { (SARS, 2008f). }\end{array}$ & $\begin{array}{l}\text { - Yes } \\
\text { - This was } \\
\text { confirmed by } \\
\text { both the SARS } \\
\text { and SAICA } \\
\text { officials. }\end{array}$ \\
\hline $\begin{array}{l}\text { SMEs could be liable for } \\
\text { up to } 11 \text { different taxes } \\
\text { (Abrie \& Doussy, 2006) }\end{array}$ & $\begin{array}{l}\text { - Abolition of RSC levies in } 2006 \text { (National Treasury, } \\
\text { 2006). } \\
\text { - Abolition of stamp duty in } 2009 \text { (SARS, 2009f). } \\
\text { - Replacement of five taxes with only one tax (the } \\
\text { turnover tax) from } 1 \text { March } 2009 \text { (SARS, 2009a:2). } \\
\text { - Abolition of standard income tax on individuals } \\
\text { (SITE) from 1 March } 2011 \text { (SARS, } 2010 b \text { ), that will } \\
\text { reduce the employees' tax calculations and } \\
\text { disclosure requirements for small business } \\
\text { employers. }\end{array}$ & $\begin{array}{l}\text { - Yes } \\
\text { - This was } \\
\text { confirmed by } \\
\text { both the SARS } \\
\text { and SAICA } \\
\text { officials. }\end{array}$ \\
\hline
\end{tabular}

Provisional tax is the most burdensome tax

(FIAS, 2007)
- Small businesses with a taxable income of $\mathrm{Rl}$ million or less can rely on the previous year's assessment to calculate the 2 provisional tax payment (Republic of South Africa (RSA), 2008). This replaces having to make an estimate which
- Partially, as only businesses with a taxable income of Rl million or less can use the 


\begin{tabular}{|c|c|c|}
\hline Compliance burden & SARS initiatives & $\begin{array}{l}\text { SARS attempted to } \\
\text { address the burden? }\end{array}$ \\
\hline & $\begin{array}{l}\text { must be } 90 \% \text { correct to avoid penalties. } \\
\text { - However, small businesses with taxable income } \\
\text { above Rl million have to make an estimate that } \\
\text { must be } 80 \% \text { correct to avoid facing potential } \\
\text { penalties. } \\
\text { - } \quad \text { The SARS official indicated that SARS is } \\
\text { considering minimising the severity of the } \\
\text { penalties in these tough economic times]. }\end{array}$ & $\begin{array}{l}\text { simplified } \\
\text { method to } \\
\text { calculate their } 2 \\
\text { provisional } \\
\text { payment. } \\
\text { This was } \\
\text { confirmed by } \\
\text { both the SARS } \\
\text { and SAICA } \\
\text { officials. }\end{array}$ \\
\hline $\begin{array}{l}\text { One third of SMEs were } \\
\text { entirely dependent on } \\
\text { tax consultants (this } \\
\text { could increase their } \\
\text { compliance costs) } \\
\text { (Citizen Surveys \& } \\
\text { Govender, 2008) }\end{array}$ & $\begin{array}{l}\text { - Dedicated tax practitioner e-mail system } \\
\text { introduced in } 2006 \text { (Smulders \& Stiglingh, } \\
\text { 2008:623). This assistance indirectly assists small } \\
\text { businesses too. } \\
\text { - A tax practitioner unit at SARS was established in } \\
2007 \text { ensuring that practitioners were assisted } \\
\text { more timeously (SARS, 2007a:48). }\end{array}$ & $\begin{array}{l}\text { - } \text { Yes } \\
\text { - This was } \\
\text { confirmed by } \\
\text { both the SARS } \\
\text { and SAICA } \\
\text { officials. }\end{array}$ \\
\hline $\begin{array}{l}\text { It is much more } \\
\text { expensive to outsource } \\
\text { record-keeping and } \\
\text { completion of tax } \\
\text { returns than to do it in- } \\
\text { house } \\
\text { (Citizen Surveys \& } \\
\text { Govender, 2008; Upstart } \\
\text { Business Strategies, } \\
2004 \text { ) }\end{array}$ & $\begin{array}{l}\text { - The simplified turnover-based tax system for } \\
\text { micro businesses was introduced from } 1 \text { March } \\
2009 \text { with the main aim of reducing their tax } \\
\text { compliance burden. This could now be done by } \\
\text { reducing the need for a tax practitioner to assist } \\
\text { a small business with its tax affairs (SARS, } \\
2009 a: 2 ; 2009 \mathrm{~h} \text { ). } \\
\text { - [The SARS official indicated that SARS is } \\
\text { considering launching an education campaign to } \\
\text { assist small businesses in reducing their need for } \\
\text { tax practitioners]. }\end{array}$ & $\begin{array}{l}\text { - Yes } \\
\text { - This was con- } \\
\text { Firmed by both } \\
\text { The SARS and } \\
\text { SAICA officials }\end{array}$ \\
\hline $\begin{array}{l}\text { Employees' tax places a } \\
\text { high burden on SMEs } \\
\text { (Citizen Surveys \& } \\
\text { Govender, 2008) }\end{array}$ & $\begin{array}{l}\text { - In July } 2008 \text { SARS made available the e@syfile } \\
\text { software application to assist employers to } \\
\text { simplify the PAYE reconciliation process (SARS, } \\
2008 \mathrm{e} \text { ). } \\
\text { - Abolition of SITE from } 1 \text { March } 2011 \text { (SARS, } \\
2010 \text { b). Small business employers are no longer } \\
\text { required to calculate and disclose this tax. }\end{array}$ & $\begin{array}{l}\text { - Yes } \\
\text { - This was } \\
\text { confirmed by } \\
\text { both the SARS } \\
\text { and SAICA } \\
\text { officials. }\end{array}$ \\
\hline
\end{tabular}

\section{Source: Authors'compilation}

TABLE 1 makes it evident that, in most cases, SARS has responded to the tax compliance burden highlighted in the compliance study with at least one initiative or administrative reform. The areas in which SARS has neither responded nor addressed the matter at all, even partially, are the following:

- the complex language used in the tax laws (although we are aware that SARS is currently addressing this issue (SARS, 2009e:17)); 
- the lack of software to assist small businesses other than those on the turnover tax system with their record-keeping for tax purposes (SARS's role here is, however, debatable); and

- the calculation of the second provisional tax payment - although legislation (RSA, 2009:22) has been introduced to reduce this burden, small businesses with a taxable income of more than Rl million could be subject to discretionary penalties should their second provisional payment not be $80 \%$ accurate. This increases the compliance burden for these small businesses (BD0, 2009; Lester, 2008; Vanek, 2009). This initiative by SARS may require further research and amendments to ensure that the compliance burden is adequately addressed.

The findings also reveal that SARS has responded to the compliance burdens within a relatively short time period (on average, between two and three years). Considering that some of these reforms required logistical changes such as improving SARS's computer systems and informing and educating the taxpayers about these changes, this is a very encouraging finding. However, as mentioned previously, this should be interpreted with caution.

Most of the studies reviewed concluded with recommendations for both SARS and the small business sector. TABLE 2 summarises the major recommendations in these studies and, where possible, links them to initiatives introduced by SARS. The table highlights areas still requiring SARS's attention and provides insight into whether or not SARS has attempted to address the needs of small business within a reasonable period of time, considering the limitations referred to above.

\section{TABLE 2: A comparison of the recommendations to SARS's initiatives}

\begin{tabular}{|c|c|c|}
\hline Recommendations & SARS initiatives & $\begin{array}{l}\text { Attempted to address } \\
\text { recommendation? }\end{array}$ \\
\hline $\begin{array}{l}\text { Simplify tax returns } \\
\text { (Citizen Surveys \& Govender, } \\
2008 \text { ). }\end{array}$ & $\begin{array}{l}\text { - Introduction of efiling of VAT returns } \\
\text { in } 2001 \text { (SARS, 2001) and for } \\
\text { companies and individuals in } 2008 \\
\text { (SARS, n.d.). } \\
\text { SARS simplified the format of } \\
\text { income tax returns for individuals. } \\
\text { The process began in 2002, but } \\
\text { significant simplification came } \\
\text { about only in } 2007 \text { (SARS, 2007b). } \\
\text { Supporting documents no longer } \\
\text { have to be submitted with the tax } \\
\text { returns unless specifically } \\
\text { requested by SARS (SARS, 2007b). } \\
\text { Pre-populated income tax returns } \\
\text { for salaried individuals (which could } \\
\text { include sole proprietors) were } \\
\text { introduced in } 2008 \text { (SARS, 2008a). }\end{array}$ & $\begin{array}{l}\text { - Yes } \\
\text { This was confirmed by } \\
\text { both the SARS and } \\
\text { SAICA officials. }\end{array}$ \\
\hline $\begin{array}{l}\text { Establish a threshold below } \\
\text { which no tax return should be } \\
\text { submitted } \\
\text { (Citizen Surveys \& Govender, }\end{array}$ & $\begin{array}{l}\text { - Addressed for salaried employees } \\
\text { (earning below R120 } 000 \text { with other } \\
\text { requirements), but not for small } \\
\text { businesses (SARS, 2008a). }\end{array}$ & $\begin{array}{l}\text { - } \quad \text { To } \\
\text { - This was confirmed by } \\
\text { both the SARS and } \\
\text { SAICA officials. [The }\end{array}$ \\
\hline
\end{tabular}




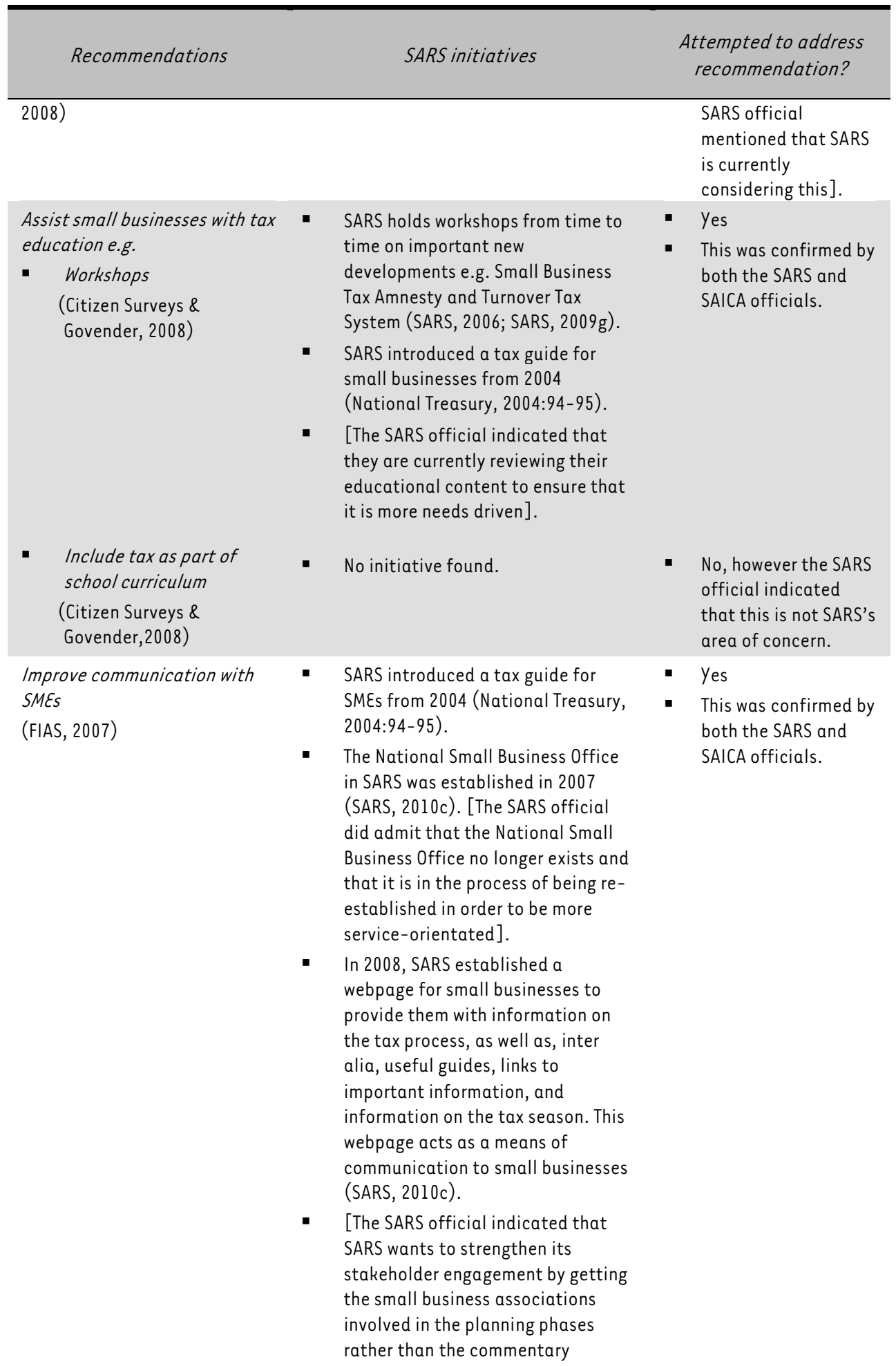




\begin{tabular}{|c|c|c|}
\hline Recommendations & SARS initiatives & $\begin{array}{l}\text { Attempted to address } \\
\text { recommendation? }\end{array}$ \\
\hline & phases]. & \\
\hline $\begin{array}{l}\text { Exempt first-time offenders } \\
\text { from penalties and interest and } \\
\text { give them insight into their } \\
\text { mistakes } \\
\text { (FIAS, 2007) }\end{array}$ & $\begin{array}{l}\text { - From } 1 \text { January } 2009 \text { Section } 75 B \\
\text { (administrative penalties) of the } \\
\text { Income Tax Act (RSA, 2008) } \\
\text { permitted a portion of or the entire } \\
\text { penalty imposed to be remitted for } \\
\text { a first-time offence (SARS, } 2010 \mathrm{~d} \text { ). } \\
\text { From 2012, this section is included } \\
\text { in Tax Administration Act (RSA, } \\
2011 \text { ) so as to apply across taxes. } \\
\text { The administrative non-compliance } \\
\text { penalties dealt with in this Act can } \\
\text { be remitted if, inter alia, the failure } \\
\text { is due to a first incidence. A first } \\
\text { incidence means that a penalty has } \\
\text { not been imposed for the past } 36 \\
\text { months (RSA, } 2011 \text { : section } 208 \text { ). } \\
\text { Thus this incorporates a first-time } \\
\text { offender. } \\
\text { A voluntary disclosure programme } \\
\text { was instituted from } 1 \text { November } \\
2010 \text { to } 31 \text { October } 2011 \text { (SARS, } \\
2010 \text { a) to avoid imposition of } \\
\text { interest. }\end{array}$ & $\begin{array}{l}\text { - } \text { Yes } \\
\text { - This was confirmed by } \\
\text { both the SARS and } \\
\text { SAICA officials. }\end{array}$ \\
\hline $\begin{array}{l}\text { Require first-time offenders to } \\
\text { attend courses instead of } \\
\text { raising penalties } \\
\text { (FIAS, 2007) }\end{array}$ & $\begin{array}{l}\text { - No initiative found. } \\
\text { [The SARS official mentioned that } \\
\text { he would recommend this action to } \\
\text { be included in SARS's educational } \\
\text { strategy plan]. }\end{array}$ & $\begin{array}{l}\text { - } \quad \text { To } \\
\text { both was confirmed by } \\
\text { SAICA officials. }\end{array}$ \\
\hline $\begin{array}{l}\text { Reduce rates for penalties and } \\
\text { interest } \\
\text { (Citizen Surveys \& Govender, } \\
2008 \text { ) }\end{array}$ & $\begin{array}{l}\text { - No initiative found. } \\
\text { (No action taken other than } \\
\text { introducing section 75B and the new } \\
\text { Tax Administration Act provisions, } \\
\text { which in certain instances (such as } \\
\text { the company having an assessed } \\
\text { loss) results in more penalties being } \\
\text { payable than before the } \\
\text { introduction of Section } 75 B \text { (Lexis } \\
\text { Nexis, nd)). }\end{array}$ & $\begin{array}{l}\text { - No } \\
\text { - This was confirmed by } \\
\text { both the SARS and } \\
\text { SAICA officials. }\end{array}$ \\
\hline
\end{tabular}

\section{Source: Authors'compilation}

This table indicates that SARS has attempted to address most of the recommendations made in the studies reviewed. Areas still requiring SARS's attention, according to TABLE 2, are the following:

- establishing a threshold below which small business tax returns need not be submitted; 
- including tax as part of the school curriculum. Although this has been implemented to a limited extent in South Africa, SARS does not introduce initiatives or give assistance (Oberholzer \& Nel, 2006:117);

- requiring first-time offenders to attend courses instead of raising penalties; and

- reducing the amounts of penalties and interest raised by SARS.

It is encouraging that even areas in TABLE 2 highlighted as receiving no attention by SARS (such as first-time offenders attending courses) are being considered by SARS for future initiatives. This will further empower small businesses in South Africa to grow and develop. However, it is suggested that SARS should still consider requiring first-time offenders to attend courses rather than raise penalties. This could allow SARS to gain a first-hand understanding of the practical difficulties faced by small business owners, as the reasons for the offence could be explained by each offender in such courses. If these small business taxpayers relied on their tax practitioners for their tax affairs, this fact will be established at these courses and the extent of this occurring will thus be ascertainable and the taxpayer or SARS can consider taking further appropriate action where necessary.

Although SARS appears to be making exceptional progress in addressing the tax compliance needs of small businesses, the above initiatives are not the only ones introduced by SARS over the last 11 years. It has introduced various other initiatives, not all of which aim to reduce compliance costs, but, in some cases, could have the unintentional consequence of increasing the compliance burden and/or costs for small businesses. A few examples of these are:

- The introduction in 2008 and 2009 of new forms: an Employer Reconciliation Declaration (EMP501), the Tax Certificate Cancellation Declaration (EMP601), the combined Employees' Tax Certificate (IRP5/IT3(a)) and an adjustment form for the

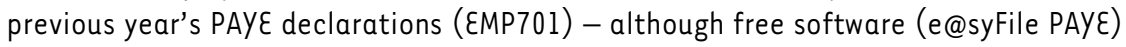
to help employers complete these forms electronically offline was provided (SARS, 2009j; SARS, 2010e);

- The requirement that employer reconciliations of employees' tax, SDL and UIF contributions be submitted twice a year rather than once a year (SARS, 2010e);

- The re-instatement of employers' obligation to obtain and maintain certain employee data and to report this data as required (SARS, 2010e); and

- The requirement that a company or close corporation must reconcile (on a ITI4SD form) its income tax, VAT, employees' tax (PAYE/UIF/SDL) and customs declarations after the initial submission of its income tax return (IT14 form) if requested to do so by SARS (SARS, 2011c:2).

The introduction of new forms, processes and returns requires either the small business owner/employee or its tax practitioner to familiarise themselves with the changes (Freedman, 2009:174). The time spent on this adds to the tax compliance burden of small businesses (Freedman, 2009:156). The exact extent of the in/decrease in the tax compliance burden/cost as a result of these changes is not yet clear and requires further investigation.

In relation to the timeliness of SARS' initiatives, it appears that SARS takes, on average, between two and five years to respond to the recommendations of the studies reviewed. This is admittedly not an accurate indication of the actual time SARS takes to respond and further detailed research is required to obtain accurate information on this matter. Nevertheless it serves as a crude platform from which to evaluate SARS's efforts. 


\section{CONCLUSION AND FUTURE RESEARCH}

This study found that SARS has attempted to address both the tax compliance burdens identified and the recommendations made in the tax compliance cost studies reviewed. The tax compliance burdens and recommendations that have only partially been addressed are as follows:

- the complexity of the language used in the tax laws;

- the lack of software to assist small businesses with their record-keeping (SARS's role in this function is, however, debatable);

- the compliance burden associated with provisional tax.

The tax compliance burdens and recommendations that have not yet been addressed are:

- the establishment of a threshold below which submission of small business tax returns is not required;

- the inclusion of tax in the South African school curriculum;

- the requirement for first-time offenders to attend courses instead of raising penalties; and

- the need for a reduction in the rates of interest and penalties raised by SARS.

It is hoped that this research will guide SARS further in its attempts to address the tax compliance burden for small businesses. It is, however, recommended that research be conducted to determine the success and effectiveness of the initiatives already introduced by SARS. This research should be conducted per initiative so as to provide valuable insights into whether the specific initiative does, in fact, alleviate the specific tax compliance burden for which it was designed. It would also highlight any areas requiring remodelling or perhaps even deletion, should the objective of the initiative no longer be met or required. It is further recommended that each new initiative introduced by SARS be thoroughly researched and evaluated before implementation to ensure that it not only achieves the intended objective but also that it does not result in an unintended compliance cost or burden for small businesses.

\section{LIST OF REFERENCES}

Abrie, W. \& Doussy, દ. (2006). Tax compliance obstacles encountered by small and medium enterprises in South Africa. Meditari: Research Journal of School of Accounting Sciences, 14(1), pp. $1-13$.

African Response. (2006). FinScope Small Business Survey Report Gauteng 2006. [0nline] Available: http://www.finscope.co.za/sme.html. (Accessed 20 August 2008)

BD0. (2009). Tax flash-August 2009. [Online] Available: http://www.bdo.co.za/documents/Tax\%20Flash\%20August\%2009.pdf. (Accessed 15 February 2010)

Citizen Surveys \& Govender, R. (2008). Draft Formal SMME Tax Compliance Survey Report. [Online] Available:

http://www.ifc.org/ifcext/fias.nsf/AttachmentsByTitle/SouthAfricaFormalSMMETaxComplianceRepor t2008/\$FILE/Formal+SMME+Tax+Compliance+Reportl.pdf. (Accessed 16 February 2010) 
Chamberlain, D. \& Smith, A. (2006). Recent findings on tax-related regulatory burden on SMMEs in South Africa - Literature review and policy options - March 2006. [Online] Available:

http://www.commerce.uct.ac.za/research_units/dpru//WorkingPapers/PDF_Files/WP_06-105.pdf. (Accessed 30 May 2006)

Clover, T.A. \& Darroch, M.A.G. (2005). Owners' perceptions of factors that constrain the survival and growth of small, medium and micro agribusinesses in Kwazulu-Natal, South Africa. Agrekom, 44(2), pp. 238-263.

Coolidge, J., llic, D. \& Kisunko, G. 2009. Small Businesses in South Africa: who outsources tax compliance work and why? Policy Research Working Paper 4873, World Bank, Investment Climate Department, Regulatory Simplification Division. [Online] Available:

http://www.wds.worldbank.org/servlet/WDSContentServer/WDSP/IB/2009/03/23/000158349_200903 23132017/Rendered/PDF/WPS4873.pdf. (Accessed 30 0ctober 2010)

Cooper, D.R. \& Schindler, P.S. (2008). Business research methods, $10^{\text {th }}$ edition. Singapore: McGrawHill/Irwin.

De Clercq, B., Tustin, D.H. \& Venter, J.M.P. (2006). The organisational impact of taxation on Small, Medium and Micro-establishments in the business services sector in Gauteng, 2006-Report 3. 2006. Pretoria: Department of Taxation, UNISA.

DTI. (2005). Integrated strategy on the promotion of entrepreneurship and small enterprises. Pretoria: Government Printer

FIAS. (2007). Tax compliance burden for small businesses: A survey of tax practitioners. [Online] Available:

http://www.ifc.org/ifcext/fias.nsf/AttachmentsByTitle/FIAS_tax_practioners_report_SA/\$FILE/FIAS _Tax_Practitioners_Report___FINAL_29+Aug.pdf. (Accessed 16 February 2010)

FIAS. (2008). Tax compliance costs for small businesses in South Africa; Web survey of tax practitioners provincial data analysis. [Online] Available:

http://www.ifc.org/ifcext/fias.nsf/AttachmentsByTitle/SouthAfricaTaxComplianceCosts2008/\$FILE/ South+Africa+Tax+Compliance+Costsl.pdf. (Accessed 16 February 2010)

FinScope. (2010). FinScope South Africa Small Business Survey 2010. [0nline] Available: http://www.finscope.co.za/new/pages/Initiatives/SmallBusiness.aspx?randomID=bfecc2e2-f62d4alb-846f-eff257aea785\&link Path=3\&IID=3_3. (Accessed 26 May 2011)

Freedman, J. (2009). Reforming the business tax system: Does size matter? Fundamental issues in small business taxation. In: C. Evans \& R. Krever (eds.) Australian Business tax reform in retrospect and prospect, pp. 153-178. Sydney: Thomson Reuters.

Gordon Institute of Business Sciences. (2010). The entrepreneurial dialogues, state of entrepreneurship in South Africa. [Online] Available:

http://www.gibs.co.za/SiteResources/documents/The\%20Entrepreneurial\%20Dialogues\%20\%20State\%20of\%20Entrepreneurship\%20in\%20South\%20Africa.pdf. (Accessed 24 May 2012)

Guyton, J.L., O'Hare, J.F., Stavrianos, M.P. \& Toder, E.J. (2003). Estimating the compliance cost of the US individual income tax. National Tax Journal, 56(3), pp. 673-688.

Hassan, M. (2011). Top five budget tips... for the Minister - Press release Monday 21 February 2011. [Online] Available:

https://www.saica.co.za/News/NewsArticlesandPressmediareleases/tabid/695/itemid/2837/langua ge/en-ZA/Default.aspx. (Accessed 12 October 2011) 
Lester, M. (2008). It's the end of provisional tax as we know it!. Business Times. 26 0ctober 2008 (Accessed 16 February 2010)

LexisNexis. (2009). Knowing your rights will make negotiating new tax legislation easier. [Online] Available: http://www.lexisnexis.co.za/media/press-release. aspx?id=1263802855713605. (Accessed 16 February 2010)

Manuel, T. (2005). 2005 Budget speech - background briefing for journalists: empowering small businesses. [Online] Available: http://www.sars.gov.za/media/media budget 2005. (Accessed 15 February 2011)

National Treasury. (2001). 2001 Budget Review. Pretoria: Government Printer.

National Treasury. (2004). 2004 Budget Review. Pretoria: Government Printer.

National Treasury. (2005). 2005 Budget Review. Pretoria: Government Printer.

National Treasury. (2006). Media statement: Response to unfounded claims by the city of Cape Town of unfair allocations to the city by the National Treasury. [Online] Available: http://www.treasury.gov.za/comm_media/press/2009/2009022001.pdf. (Accessed 15 February 2010)

National Treasury. (2011). Budget review 2011. [Online] Available: http://www.sars.gov.za/home.asp?pid=66388. (Accessed 4 August 2011)

Oberholzer, R, \& Nel, M. (2006). The road to an improved tax curriculum in South African schools. Education as Change, 10 (1), pp. 105-120.

Qabaka, V. (2011). Does our current tax system really support small business? TaxTalk, May/June, pp. $14-17$.

Republic of South Africa (RSA). (2008). Section 75B of the Income Tax Act. Government Gazette, 522(31764), pp. 1-56.

Republic of South Africa (RSA). (2009). Paragraph 20 of the Fourth Schedule to the Income Tax Act. Government Gazette, 531(32611), pp. 1-62.

Republic of South Africa (RSA). (2011). Tax Administration Act, No. 28 of 2011. [Online] Available: http://www.sars.gov.za/home.asp?pid=5923. (Accessed 12 July 2012)

Retief, દ. (2011). SAIPA welcomes budget 2011: urges more action on cost of doing business. [Online] Available: http://www.publiceyenews.com/2011/02/25/saipa-welcomes-budget-2011-urges-moreaction-on-cost-of-doing-business/. (Accessed 2 August 2011)

SARS. (n.d.). SARS Efiling. [Online] Available: http://www.sarsefiling.co.za/AboutPage.aspx. (Accessed 15 February 2010)

SARS. (2001). Efiling. VATNews - 17 August 2001. [Online] Available:

http://www.sars.gov.za/home.asp?pid=47324. (Accessed 15 February 2010)

SARS. (2003). South African Revenue Service Annual Report 2003. [Online] Available:

http://www.info.gov.za/view/DownloadFileAction?id=115258. (Accessed 16 February 2010)

SARS. (2005a). SMME facilitation programme: Report version. South African Revenue Service: Pretoria.

SARS. (2005b). Notice to Employers No 3/2005 - July 2005. [Online] Available: http://www.sars.gov.za/home.asp?pid=190\#. (Accessed 16 February 2010) 
SARS. (2006). Briefing note on small business tax amnesty 2006. Media release. [0nline] Available: http://www.sars.gov.za/home.asp?pid=2476\&toolid=2\&itemid=2553. (Accessed 11 February 2010)

SARS. (2007a). Annual Report. Pretoria: South African Revenue Services.

SARS. (2007b). The announcement of new income tax returns and filing process. Press statement issued on 9 May 2007. [Online] Available: http://www.sars.gov.za. (Accessed 5 August 2009)

SARS. (2008a). Annual Report. Pretoria: South African Revenue Services.

SARS. (2008b). More about small businesses. [Online] Available:

http://www.sars.co.za/home.asp?pid=46185. (Accessed 6 July 2008)

SARS. (2008c). VAT registration process simplified. Press statement issued on 1 February 2009.

[Online] Available: http:www.sars.co.za. (Accessed 6 August 2009)

SARS. (2008d). efiling guide for employers. [Online] Available:

http://www.psiberworks.com/Portals/0/Documentation/eFilingMANUAL.pdf. (Accessed ll February 2010)

SARS. (2008e). Filing for all employers begins. Press statement issued on 1 July 2008. [Online] Available: http:www.sars.co.za. (Accessed 3 September 2009)

SARS. (2008f). Tax season 2008. [Online] Available: http://www.sars.gov.za/home.asp?pid=11159. (Accessed 11 February 2010)

SARS. (2009a). Tax Guide for Micro Businesses 2009/10. Pretoria: South African Revenue Services.

SARS. (2009b). Turnover tax flyer - Introducing turnover tax. 2009. [Online] Available: http://www.sars.gov.za/home.asp?pid=43122. (Accessed 10 February 2010)

SARS. (2009c). VAT News No. 33 February 2009. Pretoria: South African Revenue Service

SARS. (2009d). What is efiling? [Online] Available: http://www.sarsefiling.co.za/aboutpage.aspx. (Accessed 31 July 2009)

SARS. (2009e). Budget 2009/2010 tax proposals 2009/2010. 2009. [0nline] Available: http://www.sars.gov.za/home.asp?pid=41116. (Accessed 11 February 2010)

SARS. (2009f). SARS announces abolition of Stamp Duty. Media Release issued on 31 March 2009.

[Online] Available: http://www.sars.gov.za/home.asp?PID=4232\&ToolID=2\&ltemID=45351.

(Accessed 15 February 2010)

SARS. (2009g). Taxpayer education workshops. 2009. [Online] Available: http://www.sars.gov.za/home.asp?pid=217. (Accessed 11 February 2010)

SARS. (2009h). Types of taxes - turnover tax: the benefits of turnover tax [Online] Available: http://www.sars.gov.za/home.asp?pid=43122\#benefitsofturnovertax. (Accessed 31 July 2009)

SARS. (2009i). Release of the Draft Tax Administration Bill for public comment. Media release issued on 30 October 2009. [Online] Available:

http://www.sars.gov.za/home.asp?PID=4232\&ToolID=2\&ItemID=52876. (Accessed 15 February 2010)

SARS. (2009j). Tax season 2009. Practitioner Notice Number 22/2009 issued on 21 July 2009. [Online] Available: http://www.saipa.co.za/documents/Practitioners\%20newsletter\%20222009.pdf.

(Accessed 16 February 2010)

SARS. (2009k). Quick guide to advanced tax rulings. [Online] Available:

http://www.sars.gov.za/home.asp?pid=4109. (Accessed 10 February 2010) 
SARS. (2010a). Budget 2010/2011 tax proposals. [Online] Available:

http://www.sars.gov.za/home.asp?pid=55410. (Accessed 18 February 2010)

SARS. (2010b). Budget 2010/2011 tax highlights. [Online] Available:

http://www.sars.gov.za/home.asp?pid=55410. (Accessed 18 February 2010)

SARS. (2010c). More about small business. [Online] Available:

http://www.sars.gov.za/home.asp?pid=46185. (Accessed 10 February 2010)

SARS. (2010d). Tough new penalties for taxpayers with outstanding income tax returns. [Online] Available: http://www.sars.gov.za/home.asp?pid=52276. (Accessed 10 February 2010)

SARS. (2010e). Changes to PAYE 2010: A quick guide for employers. [Online] Available: http://www.sars.gov.za/home.asp?pid=187. (Accessed 10 February 2010)

SARS. (2011a). Excel workbook to assist with recordkeeping for turnover tax. [Online] Available: http://www.sars.gov.za/home.asp?pid=43122\#10. (Accessed 27 September 2012)

SARS. (2011b). Introduction of the dynamic value-added tax vendor declaration form (VAT 201) [Online] Available: http://www.sars.gov.za/uploads/images/0_VAT_201_Letter_eFiling.pdf. Accessed 27 September 2012)

SARS. (2011c). External frequently asked questions supplementary declaration for companies and close corporations (ITI4SD). [Online] Available:

http://www.sars.gov.za/home.asp?pid=4150\&tid=65\&s=pubs\&show=1336. (Accessed 27 September 2012)

SARS. (2012a). 2011 Practitioners statistics and facts. [Online] Available:

http://sars.gov.za/home.asp?pid=3623. (Accessed22 May 2012)

SARS. (2012b). Tax proposals budget 2012. [Online] Available:

http://www.sars.gov.za/home.asp?pid=292. (Accessed22 May 2012)

Small Business Project. (2003). SME Alert - October 2003. A small business perspective on tax compliance. [Online] Available:

http://www.sbp.org.za/uploads/media/SME_Alert_A_small_business_pespective_on_tax_complian ce_0ctober_2003.pdf. (Accessed 10 February 2010)

Smulders, S. (2006). Taxation compliance burden for small business in South Africa. Unpublished Masters thesis. Pretoria: University of Pretoria.

Smulders, S. \& Stiglingh, M. (2008). Research findings: The progress of South African Revenue Services on its services quality journey. Journal of Public Administration, 43(4), pp. 607-628.

Smulders, S. \& Stiglingh, M. (2009). Comments on the Turnover Tax Legislation-25 June 2009. Submission to National Treasury. Pretoria: University of Pretoria.

Statistics South Africa. (2010). Annual financial statistics 2009. [Online] Available: http://www.statssa.gov.za/publications/statsdownload.asp?PPN=p0021\&SCH=4768. (Accessed: 4 September 2011)

Strategic Business Partnerships (SBP). (2005). Counting the cost of red tape for business in South Africa-Main Report, June 2005. Johannesburg: Strategic Business Partnerships.

Tustin, D.H., Abrie, W., Basson, J.P.C., de Clercq, B., de Hart, K.L., Doussy, E., Graham, C.R., Hammel, E.H., Howell, R., Olivier, P., Posthumus, L.C., Steyn, M., Swanepoel, A., Ungerer, M., Venter, J.M.P. \& Wentzel, M.S.I. (2005). The status of tax management and administrative skills of SME manufacturers: Gauteng 2005 - Report 1. October 2005. Pretoria: Department of Taxation, UNISA. 
Tustin, D.H., de Clercq, B. \& Venter, J.M.P. (2006). The impact of taxation on SME retailers in Gauteng - Report 2. Pretoria: Department of Taxation, UNISA.

Upstart Business Strategies. (2004). Measurement of Value Added Tax Act and Regional Services Councils Act-induced administrative burdens for South African small businesses. Final Report. Johannesburg: Upstart Business Strategies.

Vanek, M. 2009. Changes to provisional tax - a tax nightmare for many. [Online] Available: http://www.saica.co.za/Portals/0/news/Changes\%20to\%20provisional\%20tax\%20a\%20tax\%20night mare\%20for\%20many.pdf. (Accessed 15 February 2010)

Venter, J.M.P. \& De Clercq, B. 2007. A three-sector comparative study of the impact of taxation on small and medium enterprises. Meditari: Research Journal of the School of Accounting Sciences, 15(2), pp. 131-151.

World Bank \& International Finance Corporation. (2006). Doing Business 2007: How to reform. [Online] Available: http://www.doingbusiness.org/documents/Doingbusiness2007_Fullreport.pdf. (Accessed 15 February 2010)

World Bank \& International Finance Corporation. (2007). Doing Business 2008: Comparing regulation in 178 economies. [Online] Available: http://www.doingbusiness.org/documents/DB-2008overview.pdf. (Accessed 15 February 2010)

World Bank \& International Finance Corporation. (2008). Doing Business 2009: Comparing regulation in 181 economies. [Online] Available:

http://www.doingbusiness.org/Documents/FullReport/2009/DB_2009_English.pdf. (Accessed: 15 February 2010)

World Bank \& International Finance Corporation. (2009). Doing Business 2010: South Africa. [Online] Available: http://www.doingbusiness.org/Documents/CountryProfiles/ZAF.pdf. (Accessed: 15 February 2010)

World Bank \& International Finance Corporation. (2010). Doing Business 2011: South Africa. [Online] Available: http://www.doingbusiness.org/data/exploreeconomies/south-africa/. (Accessed: 2 September 2011)

World Bank \& International Finance Corporation. (2011). Doing Business 2012: South Africa. [Online] Available: http://www.doingbusiness.org/data/exploreeconomies/south-africa/\#paying-taxes. (Accessed 2 September 2011) 


\section{ANNEXURE A: List of studies found by Smulders}

The following is a list of the studies found by Smulders (2006:58-59) dealing with the tax compliance burden or costs for small businesses in South Africa:

1. Owners' perceptions of factors that constrain the survival and growth of small, medium and micro agri-businesses in Kwazulu-Natal, South Africa (Clover \& Darroch, 2005).

2. SMME Facilitation Programme (SARS, 2005a).

3. Counting the cost of red tape for business in South Africa (SBP, 2005).

4. Measurement of Value Added Tax Act and Regional Services Councils Act - induced administrative burdens for South African small businesses (Upstart Business Strategies, 2004), commissioned by the Department of Trade and Industry.

5. The status of tax management and administrative skills of SME manufacturers: Gauteng 2005 - Report 1 (Tustin, Abrie, Basson, de Clercq, de Hart, Doussy, Graham, Hammel, Howell, Olivier, Posthumus, Steyn, Swanepoel, Ungerer, Venter \& Wentzel, 2005).

6. The impact of taxation on SME retailers in Gauteng, 2006 - Report 2 (Tustin et al., 2006a).

7. The organisational impact of taxation on small, medium and micro-establishments in the business services sector in Gauteng - Report 3 (De Clercq et al., 2006).

8. Recent findings on tax-related regulatory burden on SMMEs in South Africa (Chamberlain \& Smith, 2006).

9. Doing Business in 2007: How to reform (World Bank \& International Finance Corporation, 2006). 


\section{ANNEXURE B: List of studies reviewed}

The additional studies found that deal, either completely or to some extent, with the tax compliance burden or costs for small businesses in South Africa are as follows:

1. Tax compliance obstacles encountered by small and medium enterprises in South Africa (Abrie \& Doussy, 2006).

2. A three sector comparative study of the impact of taxation on small and medium enterprises (Venter \& De Clerq, 2007).

3. Tax compliance burden for small businesses: A survey of tax practitioners (FIAS, 2007)

4. Forma/ SMME tax compliance survey report (Citizen Surveys \& Govender, 2008).

5. Tax compliance costs for small businesses in South Africa web survey of tax practitioners provincial data analysis (FIAS, 2008).

6. Doing Business 2008: Comparing regulation in 178 economies (World Bank \& International Finance Corporation, 2007).

7. Doing Business 2009: Comparing regulation in 181 economies (World Bank \& International Finance Corporation, 2008).

8. Doing business 2010 South Africa (World Bank \& International Finance Corporation, 2009).

9. Doing business 2011 South Africa (World Bank \& International Finance Corporation, 2010).

10. Doing business 2012 South Africa (World Bank \& International Finance Corporation, 2011) 